\title{
Whither IR? Multiplicity, relations, and the paradox of International
}

\section{Relations}

\author{
Brieg Powel, University of Exeter
}

Email: b.t.powel2@exeter.ac.uk

\section{Abstract}

Justin Rosenberg rightly highlights the paucity of International Relations' (IR) influence in other disciplines, and selected works in historical sociology demonstrate the significance of the international to others whilst also revealing problematic understandings of the international itself. In this regard, Rosenberg's intervention is welcome. However, in staking the disciplinary credentials of IR) on 'societal multiplicity', Rosenberg inadvertently exposes IR as part of a wider convergence on the ontological importance of relations (rather than substances) across the social sciences. Historical sociology scholarship also reveals the international to be but one part of an interconnected, multi-scalar social world that is shaped by multiplicity across all scales; multiplicity and relations permeate social scales. By exploring the Czechoslovak Corps in the Russian Revolution, the article broadens Rosenberg's multiplicity whilst also revealing the paradox of a multiplicitous IR: the more IR acknowledges multi-scalar relations, the less distinguishable it becomes from the other social sciences.

Keywords: multiplicity; historical sociology; relational sociology; International Relations; ontology

Introduction

International Relations (IR) suffers from a well-documented and historic failure to make significant inroads into other disciplines (Hoffmann, 1959; Wight, 1966; Halliday, 1994; Buzan and Little, 2001; Brown, 2013. Cf. Rosenberg, 2017:96). Justin Rosenberg (2016; 2017) seeks to address this lack of influence in his call for IR to escape 'the prison of Political Science'. This prison limits IR to being a subfield of an 'alien discipline', able to comment only on the consequences of an absence of centralised authority in the international; a space above and beyond states but occupied by them. This statist, anarchical, and subsidiary identity prevents IR from 'realizing its own potential as a viewpoint on the social world' (Rosenberg, 2016:134). Consequently, IR resembles a prison inmate as it can receive methodological and theoretical 
innovations from other disciplines but 'cannot send anything back in return'. Rosenberg seeks IR's prison break to establish IR as a discipline in its own right, with its own distinctive contribution on the social world within the social sciences.

This article commends Rosenberg for his ambition, revealing misconceptions of the international in historical sociology that might, with greater input from IR, produce more comprehensive conclusions. This is outlined in the first part of this article. Yet it also warns of an existential danger to IR: historical sociology reveals that an IR based on a theory of uneven and combined development (UCD) makes it less distinguishable as a discipline from other social sciences. The article highlights an ontological convergence around relationalism linked to 'global turns' taken across History and Sociology. The second part demonstrates how 'global turns' are making other disciplines more attuned to causal influences across multiple scales of the social world, including the international. Whilst this provides an opportunity for IR to contribute to current debates, convergence carries with it the existential threat to IR of other disciplines claiming the international for themselves. Thus, as other disciplines become more multi-scalar in approach, and consequently more attuned to the international, societal multiplicity is revealed at and across every level of human existence. This makes the present a crucial time in the development of the social sciences in general and IR in particular, and IR must respond effectively to the challenge if it is to survive.

The second part also argues that Rosenberg's understanding of societal multiplicity lacks the emphasis on continuous and overlapping relations that is evident in other branches of the social sciences. Drawing on the historical sociology of Michael Mann, among others, the article makes the case for a multiplicity that is sensitive to relations, the permeability of social forms, and the problems associated with the unitary implications of the term 'society' itself. Expanding Rosenberg's multiplicity in line with such findings will provide more comprehensive multi-scalar accounts of social processes whilst also helping IR establish itself as the only social science that explores the empirical and theoretical implications of 'the co-existence of a multiplicity of social entities' (Rosenberg, 2016:130) across multiple social scales. Herein lies IR's reformed raison d'être, as the go-to conceptual forum on the international and multiplicity that informs and engages the global turns of other disciplines.

To demonstrate its case for reforming multiplicity, the third and final part of the article explores histories of the Czechoslovak Corps in Russia between 1917 and 1920. The Corps is 
significant as a participating social actor in the revolution that led Leon Trotsky, Rosenberg's theoretical inspiration, to develop his UCD theory. Its neglect by Trotsky and Rosenberg, however, means that their use of UCD misses the overlapping and temporal dimensions of relations that are crucial in the construction of the present according to other branches of the social sciences.

\section{Desiring an international}

Justin Rosenberg's contention that IR has failed to resonate with other disciplines is especially evident when one considers studies that tread similar ground to it. Historical sociology, an interdisciplinary branch of the social sciences that draws on Sociology and History, frequently explores issues common to IR, including states (Poggi, 1978; Tilly, 1992; Strayer, 2005; Lachmann, 2010), power relations (Mann, 2012a; 2012b; 2012c), and revolutions (Skocpol, 2015). This has driven many in IR, including Rosenberg himself, to extol the virtues of historical sociology for the discipline (Hobden and Hobson, 2002; Lawson, 2006; Rosenberg, 2006; Anievas and Matin, 2016). Indeed, historical sociology has enjoyed a steady influence within IR, informing studies of, for instance: state formation and decay (Matin, 2007; 2018); the Peace of Westphalia (Spruyt, 1994); global capitalism (Hobson, 2017); the 'rise' of the West (Anievas and Nişancoğlu, 2015); revolutions (Halliday, 1999; Lawson, 2015; 2017); warfare and militarism (Barkawi, 2006, 2017a, 2017b; Mabee and Vucetic, 2018); and piracy (Colás and Mabee, 2010; Leira and De Carvalho, 2010). This suggests natural opportunities for dialogue between historical sociology and IR. Too often, however, studies in historical sociology outside IR rarely engage with the international beyond merely suggesting its character and composition.

Works by three historical sociologists who explore concepts and processes common to IR studies, Michael Mann, Richard Lachmann, and Charles Tilly, are indicative of this malaise. Mann's kaleidoscopic exploration of power across the globe acknowledges a space above and beyond the states and societies that helps shape his case studies. He identifies inter-state warfare and competition as drivers of class relations and social revolutions (Mann, 2012a:chs. 12-15; 2012b:chs. 5, 6, 7, 18), and of British and German industrialization (Mann, 2012b: chs. 4, 9). In response to criticism of his portrayal of the international (see Hobson, 2006), Mann (2012a: xv) also highlights the ideological and economic aspects of 'extra-state space'. Despite 
the importance of the international to his work, however, a clear formulation of it remains missing from Mann's work. This leaves the reader clear on the international's significance but unaware of its dynamics beyond war and inter-state competition.

In another study of states and power, Richard Lachmann concludes that 'states came into existence when elites and their organizational capacities were combined into a single institution' (Lachmann, 2010:62). Lachmann offers a largely internalist and Eurocentric explanation of state-formation, based on the finding that elites centralized themselves into states. Nevertheless, Lachmann also observes that protection against foreign invaders was a key motivator of state centralization in Russia, Eastern Europe, and the Netherlands. In addition, once state consolidation occurred elites in Britain, France, Spain, the Netherlands, and Russia used their new-found state capacities 'to launch wars against foreigners and to seize colonies'. Therefore, whereas the international cannot be ignored in Lachmann's account, it is defined purely by binary military mentalities: defensive, as threats of invasion from others, or offensive, in the form of opportunities for conquest. This noticeably reiterates the defensive/offensive dichotomy within realist approaches in IR.

Similarly, Charles Tilly's oft-quipped aphorism that 'war makes states and states make war' itself rests on the premise that there is a space outside the state, inhabited by other states, wherein the state can make war. Tilly (1992:9-10) readily engages with IR scholarship in his work on state formation, drawing on James Rosenau (1970), William Thompson (1988), and Kenneth Waltz (1979). He concludes that IR provides a 'valuable corrective to the internalism of statist analyses' of state formation (Tilly, 1992:9). Yet Tilly's treatment of IR purely as 'geopolitical approaches' is emblematic of Rosenberg's observation that other disciplines rarely extend their consultation of IR 'beyond a narrow argument about geopolitics' (2016:129). Tilly's analysis reveals that European states faced a varying degree of military, economic, and diplomatic pressures from the international, driving similar but not identical state-formation processes (cf. Barkawi, 2017a:60). Thus, just as is the case with Mann and Lachmann, Tilly appreciates the constitutive influence of the international whilst avoiding conceptual engagement with the international itself. Tilly's grasp of IR scholarship remains overwhelmingly realist in orientation, reiterating Mann and Lachmann's anarchical, competitive international rather than recognising the productive, co-constitutive, multilayered space commonly documented in more critical IR studies. 
Flaws with Tilly's understanding of the international are appreciated within Sociology. Julian Go (2016:89-90) notes the absence of the international beyond Europe in the Tilly's thesis on 'national state' formation, ignoring the imperial dimensions of the development of the states that Tilly analyses. A similar blindness towards empire and the non-Western also emerges in Mann's final volumes of The Sources of Social Power. These depart from the more global perspectives of earlier volumes into an analysis centred on 'leading edge' states, the United Kingdom and the United States. Mann does so without recognising their imperial nature and all that entailed to his understanding of power (Go, 2016:110). Similarly, George Steinmetz demonstrates the paucity of Mann, Tilly, and others' readings of the colonial state, finding that the 'hard' structures of colonial states were constituted by and through relations between colonizers, their metropole, and the colonized. Colonial states were not simply mass replications of European state on colonies and thus less uniform in character than what is often assumed (Steinmetz, 2007:517).

By reading Go and Steinmetz, one also comes to appreciate the more complex and productive social impact international relations have on multiple social scales. ${ }^{1}$ Similarly, Nitsan Chorev's work on US trade policy (2007) demonstrates at length the mutually-constitutive effects of international relations on domestic and state-level social entities. She finds (2007:198) that 'it is at the domestic level that interstate cooperation is made possible', through the generation of popular consent and the establishment or reconfiguration of domestic institutions to allow for a globalized international financial system. In so doing, Chorev indirectly undermines the claims of an anarchical realist international within Sociology and beyond. Tarak Barkawi also considers globalization, albeit in relation to war (2006). He reveals war as a producer of globalization just as globalization generates conflict. Elsewhere (2017b), he demonstrates that whilst imperial militaries, such as the British-Indian, may have initially sought to enforce essentialised identities on their membership and parent societies, these were shattered and reconfigured by the relational realities of global war.

Such sociological and historical sociological scholarship reinforce Rosenberg's point that international relations go far beyond competition and conflict. Yet they also suggest an emergent sophistication in other social sciences' understandings of the international beyond

\footnotetext{
${ }^{1}$ Thanks to one of the anonymous reviewers for making this point.
} 
what Rosenberg perceives. More generally, however, the international remains undertheorized in historical sociology (Go and Lawson, 2017:11-12). Mann, Lachmann, and Tilly's studies of states, state formation, and power are symptomatic of this malaise, despite each being appreciative of the international's formative influence in their work. These only superficially touch on the wealth of insights produced by IR, with historical sociology's shared foci accentuating the weakness of IR's influence on related disciplines. Part of the problem stems from the limited awareness of critical IR scholarship evident in historical sociology, demonstrated by Tilly's selective reading of IR. This presents an ideal opportunity for IR to engage with such literature, problematizing their findings with its own more comprehensive engagement with the international. Yet, by revealing a more related, multi-scaled social world than is often evident in the social sciences, Mann, Lachmann, and Tilly along with the more sophisticated analyses of Go, Steinmetz, and Chorev expose an existential challenge for IR itself. They show the inseparability of any given social entity from others on and across surrounding social scales including, as the next section demonstrates, overlapping networks of relations and the necessarily-composite and fluid essence of any social entity. Worryingly for IR, this calls into question the entire notion of a separate, distinctive international space and the need for a discipline that is parochially limited to its study.

\section{The multi-scalar and relational social}

Societal multiplicity is predicated on three assumptions: first, that there are such things as social forms; second, that these are multiple; and, third, that these interact with each other. Whilst Rosenberg may have been first in appreciating the significance of societal multiplicity (see for example: Rosenberg, 2006), he is not alone. For example, Julian Go and George Lawson (2017:20) echo Rosenberg's work in observing that 'the simultaneous existence of multiplicity and interactivity - "interactive multiplicity" - is what constitutes the field of International Relations'. Yet Rosenberg's understanding of multiplicity is not limited to the international:

the word "international" always ends up presupposing the same basic circumstance, namely, that human existence is not unitary but multiple [in that] it is distributed across numerous interactive societies (Rosenberg, 2016:135; emphasis added).

This significant claim reaches beyond any single social scale, such as the international. However, this carries difficult implications for both Rosenberg's thesis and for IR: if all human 
existence is multiple, what is so unique about the international? By extension, if IR's claim to disciplinary distinctiveness is predicated on the international being distinctive, then would not a realisation that multiplicity is common across all social scales, and therefore that the international is not distinctive, mean that IR itself cannot be distinctive from other social sciences?

Any response to the second question depends on whether there is consistency across the social sciences regarding multiplicity as a defining feature of human existence. Once again, historical sociology offers a useful place to explore this possibility due to its interdisciplinary congregation. Interactive multiplicity is 'what historical sociology in IR is best placed to interrogate' according to Go and Lawson, echoing others including Rosenberg himself (Hobson, Lawson, and Rosenberg, 2010). Go and Lawson's argument for the utility of historical sociology is part of an intervention in favour of a 'global historical sociology' (GHS). They implore Sociology and IR to better inform each other and the historical sociological scholarship associated with each discipline. In their eyes, historical sociology across the disciplines suffers from mutual inabilities to comprehend specific social scales. In Sociology, historical sociology is replete with internalist perspectives that explain social processes by focusing exclusively on factors within a society or a state, whereas historical sociology in IR is equally prone to an 'externalism' that siphons off the international as a wholly separate realm with unique logics (Go and Lawson, 2017:20). Their solution, GHS, is proposed as a 'metaapproach' that addresses these failures.

It is striking that Go and Lawson, their contributors, and those listed as having been affiliated with the project at different points (such as Gurminder Bhambra [Go and Lawson, 2017:ix]) are drawn from across Sociology and IR. This suggests a growing synergy across disciplines regarding interactive multiplicity. Go and Lawson aim to produce a 'transdisciplinary' space where shared concerns might be explored, thereby addressing the two-sided malaise of internalist and externalist analyses. This would complement the two other benefits of GHS, namely that it is 'historically rich and theoretically orientated' and that it reinforces existing attempts to 'world' the ontologies of Sociology and IR (Go and Lawson, 2017:24-25). Go and Lawson's challenge to their home disciplines, therefore, can be summarised as being a call for a better appreciation of scales traditionally excluded from analyses. That their project 
includes scholars from both Sociology and IR suggests that multiplicity, as Rosenberg proposes, is indeed a basic circumstance of human existence per se.

Go and Lawson's concern over internalism and externalism is, however, somewhat at odds with Mann, Lachmann, and Tilly. The latter's problem is not so much an absolute ignorance of the international but rather an uncritical acceptance of a realist account of the international. Rosenberg's reimagined IR and Go and Lawson's GHS are well-placed to address Mann, Lachmann, and Tilly's shortcomings. Yet it is also important to appreciate some of the historical sociologists' wider appreciation of interconnectivity across different social scales, and their recognition of the permeability of social boundaries to ideational, material, and demographic flows. Global history, a sub-field of History, is arriving at similar conclusions regarding multi-scalar interconnectivity. Global history, argues Conrad (2016:65), should be open to exploring 'alternative notions of space' from the macro right through to the micro, and reject exclusively internalist or externalist approaches. Richard Drayton and David Motadel (2018:13) propose that global history is:

\footnotetext{
an invitation to the historian to be self-conscious of the jeux d'échelles, of the interdependence of the scales of space - village, province, nation, region, and world - and time - days, decades, centuries - through which we explore and explain the past.
}

Thus, no matter at which 'scale' or level of social life that the object of study exists, one needs to recognise the interactions between that scale and others. This does not mean that all historical processes must have been caused by a 'global' factor, but rather that extraterritorial factors may have been influential and that research needs to be open to that possibility (see Conrad, 2016:71-72). This prevents internalist and genealogical causal explanations that ignore factors from beyond the spatial frameworks that are most immediately apparent.

Conrad's argument is also a reminder to IR that externalist approaches are problematic, even if, as Rosenberg (2016:139) argues, "the international" imparts its own dialectical mechanisms and dynamics to the structure of world history'. Lawson $(2015 ; 2017)$ brings similar multi-scale thinking to his global historical sociology of revolutions, advocating an 'intersocial approach' to reveal how 'differentially located, but interactively engaged, social sites affect causal pathways' (Lawson, 2017:89). Revolutions cannot be understood as being exclusively grounded in a specific site; sites across different social scales are forever 
interacting, with the interaction forming and re-forming the social forms involved. The broader point, therefore, is that understanding socio-political change in both historical sociology and global history demands an openness to causal factors at all scales, with none considered to be insulated from the others.

Such multi-scalar approaches suggest space for dialogue across IR, historical sociology, and global history. Indeed, this is already being encouraged within IR (for example: Lawson, 2006; Rosenberg, 2006; Phillips, 2016; Spruyt, 2017), and it might easily be broadened to sociology given Go, Steinmetz, and Chorev's multi-scalar sensitivities. These 'global turns', so to speak, demonstrate that $I R$ is increasingly accompanied in exploring the international. From Rosenberg and Go and Lawson to Mann, Conrad, and Drayton and Motadel, there is a discernible convergent ontological shift towards relations as being the core of social processes. Indeed, none of Rosenberg's five 'consequences' of multiplicity - co-existence, difference, interaction, combination, and dialectical change - are possible without relations (Rosenberg, 2016:135-141). Relations are fundamental to Rosenberg's (2016:136) 'positive' international of 'multiple interacting societies' and represent the 'interactive' component of Go and Lawson's 'interactive multiplicity'.

Nevertheless, a focus on relations remains a radical methodological shift in emphasis for IR, Sociology, and History, alike. It is a move away from exploring substances and entities - states, nations, societies, organisations and so on - to consider the spaces and interactions between them. Mustafa Emirbayer's pioneering sociological study of relational approaches, proceeds from the question of 'whether to conceive of the social world as consisting primarily in substances or in processes, in static "things" or in dynamic, unfolding relations' (Emirbayer, 1997:281). For Emirbayer, social scientific approaches that have been dominant over the last half-century, such as rational-actor or norm-based models, quantitative statistical variable analyses, and various structuralisms, are all limited by a 'substantialist' understanding of the social world that ignores the dynamism of relations. In substantialist approaches, entities are understood to exist before relations, rather than as emerging because of and through relations, whilst also possessing fixed interests, goals, norms, and identities (Emirbayer, 1997: 284-286).

In IR, Patrick Jackson and Daniel Nexon argue that entities are assumed to be fixed by many in the discipline, highlighting the case of Wendtian constructivism and neorealism. 
Constructivism proposes that state identities shift as a consequence of interaction, whilst neorealism appreciates the changing distributions of power among states within international systems. However, such apparent changes are only superficial as

entities themselves ... do not change in their constitutive properties; they remain states with the requisite attributes which define them as states. Rather, what changes are some of their variable attributes - how much power they have, the scope of their corporate identities, etc (Jackson and Nexon, 1999:293).

Substantialist approaches such as constructivism and neorealism therefore make it very difficult to appreciate change in the social world, including in the international, as they rely so heavily on substances possessing invariant characteristics for their identification as substances in the first place (Jackson and Nexon, 1999:297).

Relational approaches challenge this substantialist view. For instance, Andrew Abbott (2016:ix-x) builds his understanding of processual sociology from the recognition that

Individuals and entities are not the elements of social life, but are the patterns and regularities defined in lineages of successive events. They are moments in a lineage, moments that will themselves shape the next iteration of events even as they recede into the past.

Abbott's interweaving of social forms and temporalities is noticeable, merging what Rosenberg (2016:131-132) views as Sociology's traditional concern with History's. Go's case for a postcolonial social theory (2016) draws on Homi Bhabha's recognition of hybridity and Edward Said and Frantz Fanon's belief that colonial and metropolitan 'societies' exist in relation to each other. Correspondingly, global historian Conrad (2016:65) observes that development is 'inherently relational', and 'a historical unit - a civilization, a nation, a family - can only be understood through its interactions with others'. Furthermore, 'many groups only jelled into seemingly fixed units as a response to exchange and circulation'. Sanjay Subrahmanyam and others' works on 'connected histories' demonstrate that even supposedly 'national' empires, revolutions, and local historical development are inextricably interwoven into a global mesh of connections and relations (Subrahmanyam 1997; 2007; various in Armitage and Subrahmanyam, 2010). Relations, in other words, are what makes units; they are not 'natural' entities with given properties.

Mann and Tilly are also sensitive towards relations. Mann (2012a:2) believes that: 
A general account of societies, their structure, and their history can best be given in terms

of the interrelations of ... the four sources of social power: ideological, economic, military, and political (IEMP) relations.

Mann's IEMP approach is therefore premised on the exploration of relations, and that it is these and not the essences of societies that should be studied. Tilly is equally critical of arguments based on variation between social actors' (especially states) characteristics or essences 'rather than relations among them' (Tilly, 1992:11). In Capital, Coercion, and European States, he blames this misreading of variation between states on scholars' misplaced belief that European states were deliberately constructed differently during the nineteenth and twentieth century. In fact, he argues, the key causes of difference were the relations between polities, including the fluctuating pressures each polity experienced over time. He repeats his conviction that it is relations that determine much in the social world in a study exploring inequality, finding that 'bonds, not essences, provide the bases of durable inequality' (Tilly, 1995:48). It is possibly their respective global and European-regional points of departure that lead to Mann and Tilly to develop these relational understandings of the social world. The same cannot be said, however, of Lachmann with his internalist perspective on states. Nevertheless, even he acknowledges the international and in so doing, he too appreciates the influence of relations (in the form of competition or war) that are predicated on the condition of interactive multi-scalar multiplicity.

A realisation that relations and connections transverse multiple social scales is therefore evident across disciplines. Rosenberg's reliance on UCD reminds us of this common realisation through his location of causal factors for nominally internal events (revolutions) in the international. Rosenberg (2016:142) concludes that the 'generative international context' produced instability within Russia, wherein the grafting of a modern capitalist society 'on to a semi-feudal social structure [produced] a unique hybrid of the old and the new'. Thus, Russian politics and society developed in relation to Western capitalist states, albeit unevenly so, and the revolution has a causal factor grounded in the international. This argument is significant by revealing that multiple scales of human interaction are connected, and that the international is not ontologically separate from the domestic, as Kenneth Waltz suggests (1979; 2001). It also reveals that Rosenberg's reading of the international as being more comprehensive than those in other disciplines who may, at best, have limited their understanding of the international to the accounts of Waltz and his likes. 
Works on relations in other branches of the social sciences not only express a similar interest to Rosenberg in the interplay across social scales but also provide important lessons for his understanding of multiplicity. Central among these is the revelation that multiplicity exists not just outside and between social actors but also within and through them. As Mann (2012a:16) observed, 'human beings do not create unitary societies but a diversity of intersecting networks of social interaction'. These extend through and beyond individual societies, overlapping with other networks inside and outside a given society. Indeed, the entire notion of 'society' is problematic for Mann as it implies a unitary social totality that is impossible to achieve. 'Human beings', Mann (2012a:14) argues, 'need to enter into social power relations, but they do not enter social totalities. They are social, but not societal, animals.' There is consistency here between Mann and Rosenberg, with both recognising that human relations need to be conceptualized as multiple. For Mann, however, this is not in the sense of societal multiplicities but rather in the sense of 'multiple overlapping and intersecting sociospatial networks of power ... We can never find a single bounded society in geographical or social space' (Mann, 2012a:1).

Mann is not alone in this realisation and, once again, there is a convergence of voices across the social sciences. For instance, human geographer John Agnew (2007:141) observes that "cultures" themselves are assemblages of people with often crosscutting identities and commitments'. Emirbayer (1997:288) stresses that 'societies ... are nothing but pluralities of associated individuals'. Margaret Somers (1994:72) goes so far as to reject the term 'society' altogether, arguing that it should be replaced with 'relational setting', representing 'a patterned matrix of institutional relationships among cultural, economic, social and political practices'. Emirbayer (1997:295) concurs, believing that shifting to 'relational settings' would be especially helpful in encouraging caution when assuming nation-states as primary units of sociological analysis; a fault prevalent in IR, History, and Sociology alike. Indeed, for all disciplines, the term 'relational setting' is much more accommodating of permeability and multiplicity than 'society'.

The recognition that relational settings are rarely exclusive and regularly overlap is significant. Individuals can simultaneously be members of multiple settings, and are therefore subject to the various power relations associated with each setting. Mann (2012a:16) captures this by demonstrating that possible responses to the question 'in which society do you live?' typically 
reflect multiple relational settings, depending on the context of the conversation. Such responses expose the simultaneous association of any one individual with multiple relational settings. Moreover, it exposes a further temporal dimension to relational settings, with some aspects of a setting becoming more significant at different times. Even states, the reified central actor in realist IR, cannot be understood as unitary, exclusive, fixed objects. Instead, they are vehicles that transmit power through relational settings (Mann, 2012c:13), imposing infrastructural territorialities that cut through the spatialities of other relational settings. Despite being bifurcated by states, relational settings often persist, with relations being disrupted rather than terminated. Variation between relational settings emerge due to the diversity of overlapping relations each incorporates and the context(s) in which they occur: because the relations and the settings vary, more differentiated relational settings are produced. For instance, relational logics would operate differently if they took place in either colonial, hegemonic, or heteronomous international contexts, in turn producing different forms of relational settings. ${ }^{2}$

Taken alongside the global turns visible in works such as Go's, Chorev's, or Conrad's, Mann and Emirbayer's findings raise an existential paradox for Rosenberg's vision of IR grounded in the study of societal multiplicity: the more IR stresses combined and dialectical relations between the international and other social scales, the more IR converges with other disciplines undergoing relational global turns, thereby risking losing its distinctiveness as a discipline. On the other hand, were IR to remain fixated on an isolated, anarchical understanding of the international, its parochialism would become increasingly apparent to disciplines that are themselves becoming progressively more sophisticated in their understanding of the international. IR consequently risks not only remaining inside its prison, but possibly even placed on death row.

Nevertheless, other disciplines do not yet enjoy the breadth of awareness of the international as that evident in IR. Go (2016:115) notes that global history's more postcolonial approach challenges Sociology's own practices. However, history lacks Sociology's theoretical abstractions necessary to delineate historical enquiry, such as the meaning of 'connection' when determining 'connected histories'. To repackage Go for IR's predicament, neither

\footnotetext{
${ }^{2}$ Again, thanks to an anonymous reviewer for making this point.
} 
History or Sociology are yet to theorise on the nature of the international, only on how objects and processes within the international intersect with their primary subjects of study. Despite their global turns, therefore, IR still needs to be there to provide other disciplines with the tools and insights to help them more effectively incorporate the international as multiplicity into their multi-spatial, co-constitutive causal explorations. Geography, History, and Sociology may explore the impact of space, time, and social setting on human existence, but it is only IR that interrogates the implications of inter-societal relations that result from humans organising themselves across a multiplicity of social settings. Yet IR remains in need of finetuning its concept of multiplicity in line with findings from other social sciences on the permeability and fluidity of relational settings. As the final part of the article will demonstrate, this is evident in the very same revolution that led to the theory of uneven and combined development around which Rosenberg constructs his notion of multiplicity.

\section{The overlapping relations of the Russian Revolution}

Rosenberg is ambiguous on the permeability of 'societies', remaining preoccupied with singular state- or national-level societies in the manner of Trotsky's UCD approach. UCD is typically centred on unitary, idealised nation-state societies, such as the Russia, China, and Saudi Arabia or, in a different sense, the 'Brazilian novel' mentioned by Rosenberg (2016:147148). He is not necessarily hostile to other social forms within the multiplicity: his highlighting of the hybrid, composite, and relational development of certain polities such as Russia and Ancient Sumer (Rosenberg, 2016:145) hint at the possibility of multiplicity beyond and below the state. Yet in each instance, the influence of the international appears to end with the emergence of an example state, and there is no discussion of ongoing multi-scale relations. He shares with Theda Skocpol $(2015: 34)$ the problematic assumption that international relations are limited to being the 'midwives' of processes rather than an ongoing dimension of relational settings. This prevents us from appreciating that 'everything in the social world is constantly in the process of making, remaking, and unmaking itself (and other things)' (Abbott, 2016: ix, emphasis added). Relations do not simply stop once a 'society' has been formed, and a 'society' cannot ever be considered as fixed and final.

Rosenberg's (2016:141-143) approach derives specifically from the first chapter of Leon Trotsky's History of the Russian Revolution (2017) which outlines the conditions preceding the 
Revolution. As Rosenberg rightly argues, Trotsky's history is instructive for internalist approaches in the social sciences that neglect the constitutive dialectical relations between the international and the domestic. Yet Trotsky shares the substantialist tendencies evident in other economically-deterministic approaches, such as World Systems Theory, in assuming an essential economic structure to the international wherein 'societies' are understood purely by their role within or opposition to this global economic structure. This is a quintessentially 'holist' substantialist perspective, defined by sociologist Nick Crossley (2011:7) as being the belief that parts of the social world can only be understood and explained through their 'fit within the whole' (the global capitalist-imperialist system in Trotsky's case). The permeability, fluidity, and impermanence of social forms are therefore disregarded.

Trotsky's account is not alone in finding reasons for the outbreak of the Revolution in the international. For instance, Skocpol (2015:207) asserts that the 'Russian Revolution broke out only because - and when - the tsarist [sic] state was destroyed by the impact of prolonged involvement and repeated defeats in World War I'. For Mann (2012c:171), the international context of the Revolution was the need to 'satisfy the aspirations of the popular classes' as a general condition of 'advanced countries in the first half of the twentieth century'. Russian workers were part of a wider international pattern of early twentieth century labour unrest, socialism, and syndicalism (Mann, 2012b:chs 17-20; 2012c:172). A crucial difference between Czarist Russia and other cases was that it represented the most extreme case of despotic antiworker rule in Europe and North America, wherein workers had fewer collective and democratic rights than elsewhere (Mann, 2012c:174). Rather surprisingly given other parts of his studies of social power (see above), this is where the role of the international ends for Mann, leaving an account of the Revolution that, like Skocpol, Trotsky, and Rosenberg, ignores ongoing international relations.

Yet the significance of persistent multi-scalar relations and of overlapping relational settings is apparent in other histories of the Revolution and the associated Russian Civil War. A case in point is the history of the Czechoslovak Corps between 1917-1920. This was a force of 35,000-40,000 Czechoslovak soldiers from two armies: many from the Czechoslovak Legion in the Russian Czarist army; others being released Czechoslovak prisoners of war formerly of the Austro-Hungarian army. Were one's gaze limited to state- or national-level 'societies', the case of the Czechoslovaks, a stateless people within the Austro-Hungarian Empire, would be 
missed. Indeed, Rosenberg says nothing of the Corps. Trotsky, on the other hand, is curiously inconsistent. In his History, the Corps gets but two mentions, both in the same paragraph on a quotation from Lenin regarding the inevitability of a proletarian victory against them. Yet on 29 July 1918 he argued that the Czechoslovaks were the most important factor in deciding the questions of the Russian revolution' (Mawdsely, 2017: 62). Two months earlier, on 25 May, Trotsky understood them to have been such a threat that he issued an order to local soviets: 'Every armed Czechoslovak found on the railway is to be shot on the spot' (Figes, 1997: 576; Mawdsely, 2017: 66).

After Russian withdrawal from the World War, the Corps attempted to join the Allies on the Western Front via the Trans-Siberian railway and the Siberian port of Vladivostok. Following a brief period fighting alongside the Bolsheviks against German invaders around Bakhmach, Ukraine (Kennan, 1957: 6), a violent altercation with released Hungarian prisoners of war at Cheliabinsk on 14 May 1918, led to their Bolshevik escorts using force against the Czechoslovaks. The latter reacted, overwhelmed their chaperones and seized the vast TransSiberian railway for themselves. This snowballed into a broader revolt against the Bolsheviks that drew in various anti-Bolshevik factions which, by the end of June 1918, had taken the sizeable Siberian and Ural regions from the Reds (Mawdsley, 2017: 74-75). Orlando Figes (1997: 577) blames Trotsky's 'overreaction' to the Cheliabinsk incident for transforming the Czechoslovaks from being a disinterested party with Bolshevik-leaning members intent on leaving Russia into 'a hostile army' deep in its heartland. The Czechoslovaks' military training and experience allowed them to routinely defeat larger numbers of undisciplined and incompetently-led Reds (Figes, 1997: 577). Their influence was also crucial in encouraging Bolshevik opponents to unite behind the All Russian Provisional Government in 1918 (Figes, 1997: 580-581) and in encouraging Western Allied ambitions in Russia, including American and Japanese landings on the Siberian coast (Mawdsley, 2017: 73).

However, the Czechoslovaks' relations with another relational setting, the Austro-Hungarian Empire, proves decisive. This was always the case, as John Keegan (1998: 418) suggests by attributing the fateful Cheliabinsk incident to a clash of 'two patriotisms: that of the Czechs [sic] for an independent Czechoslovakia [and] that of the Hungarians for their privileged place in the Habsburg system'. Hence the multi-scalar dynamics of Austro-Hungarian imperialism overlap with the Russian case: first as part of a broader geopolitical conflict between empires 
(including, but also pre-dating, the First World War), and, second, as an independence struggle by a national group within the Astro-Hungarian Empire. Conrad (2016: 156) notes in his defence of global history that 'every issue requires its own temporal and spatial order'. The Czechoslovaks' case exposes the different but overlapping temporalities of the AstroHungarian and Russian 'issues', underlining how such temporal and relational overlaps can produce significant implications. The Cheliabinsk incident could have occurred in other sites where Czechoslovaks and Hungarians may have encountered each other, but the fact that it occurred in Russia at this specific point in time made this incident just as much a part of the 'Russian' story as it was part of the Czechoslovak/Austro-Hungarian story.

By mid-August, many Czechs were tired and longed for home, with morale suffering accordingly (Figes, 1997: 581). The declaration of Czechoslovak independence from the Austro-Hungarian Empire on 28 October 1918 further re-framed relations between the Corps and the Whites, with the logic of fighting in Russia as a means of maintaining another front against the Empire becoming unsustainable. From then on, the history of the Corps in Russia is one of negotiations with the Reds and withdrawal via Vladivostok to Czechoslovakia. Thus exited a large, well-trained military force from the White side, leaving a patchwork of regional regimes to fight to the last among themselves and against the Reds (Figes, 1997: 584). Their loss of interest and eventual departure were perhaps as decisive as their initial rebellion to the broader history of the revolution (possibly also influencing Trotsky's volte face on their significance). Yet their presence within the Russian setting was always but one aspect of their multiple relations, and cannot be separated from their relations with the nationalist struggle at home nor the broader Allied war effort against the Central Powers. This demonstrates the impossibility of fully separating the international (or any other scale) from others and, crucially, the importance of ongoing multi-scalar relations. Thus, Trotsky and Rosenberg's arguments that the international is a space of uneven and combined development are accurate to a point. However, they do not go far enough to recognising the significance of continuing relations. The international is never just context alone; it is part of a relational, multi-scalar, and fluid social totality that can never be successfully divided into isolated, selfcontained, unchanging 'societies'. 


\section{Conclusion}

Growing trans-disciplinary interest in multi-scalar relations challenges those in IR and beyond who view the international as a distinctive, isolated space. Rosenberg's appreciation of multiplicity does well to point IR away from such thinking and towards the significance of the relationship between actors and across the international/domestic boundary. The historical sociologies of Mann, Lachmann, and Tilly demonstrate the poverty of many historical sociological understandings of the international, despite their recognition of the formative relationship between the international and other social scales. Nevertheless, recent global turns in History and Sociology are bringing new insights into multi-scalar relations, offering ever more sophisticated theorisations of international's impact on relational settings across various social scales. Thus IR's hitherto privileged position as the forum to explore the international is challenged just as Rosenberg urges it to flee the prison of political science. IR needs to be aware of this danger or risk becoming something of a parochial anachronism that remains preoccupied with politics in the absence of central authority and the misplaced assumption of the impermeability of the international to constitutive influences from other scales.

The repositioning of IR's ontological focus towards multiplicity offers a means of avoiding this fate. However, IR's understanding of multiplicity must first heed findings in other disciplines that share with Rosenberg an appreciation of multi-scalar causality and constitutive relations. Other disciplines' interest in the international often stems from exploring relations rather than substances, appreciating the permeability, fluidity, and mutually-constitutive aspects of relational settings whereas Rosenberg and Trotsky's UCD remains premised on unitary nation-states. Consequently, Mann and Emirbayer's questioning of the very term 'society' and Mann's recognition of the importance of ongoing relations are crucial to developing multiplicity beyond merely seeing the international as a precursory context of processes involving unitary actors. Yet herein lies the paradox of a relational IR of multiplicities: the more IR is grounded on relational ongoing multiplicity (as it should be), the less distinctive the international - and therefore IR's unique selling point - becomes. Nevertheless, regrounding IR's ontological focus on a relational, ongoing understanidg of multiplicity provides it with a more comprehensive offer to other disciplines at a time when they themselves wrestle with the constitutive influence of the international on their subjects of study. In this manner, IR 
becomes well-placed to lead the disciplinary convergence around relations and the international.

\section{Bibliography}

Abbott, A. (2016). Processual Sociology. Chicago: University of Chicago Press.

Agnew, J. (2007). Know-where: Geographies of knowledge of world politics. International Political Sociology 1(2), 138-148.

Anievas, A., \& Matin, K (eds). (2016). Historical Sociology and World History: Uneven and Combined Development over the Longue Durée. London: Rowman and Littlefield International.

Anievas, A. \& Nişancoğlu, K. (2015). How the West Came to Rule: The Geopolitical Origins of Capitalism. London: Pluto Press.

Armitage, D., \& Subrahmanyam, S. (eds). (2010). The Age of Revolutions in Global Context, c. 1760-1840. Basingstoke: Palgrave Macmillan.

Barkawi, T. (2006). Globalization and War. Lanham, MD: Rowman \& Littlefield.

Barkawi, T. (2017a). States, armies, and wars in global context. In: J Go and G Lawson (eds). Global Historical Sociology. Cambridge: Cambridge University Press, 58-75.

Barkawi, T. (2017b). Soldiers of Empire: Indian and British Armies in World War II. Cambridge, UK: Cambridge University Press.

Bell, D. (2013). This is what happens when historians overuse the idea of the network. New Republic, 26 October.

Brown, C. (2013). The poverty of grand theory. European Journal of International Relations 19(3), 483-497.

Buzan, B., \& Little, R. (2001). Why International Relations has failed as an intellectual project and what to do about it. Millennium: Journal of International Studies 30(1), 19-21.

Chorev, N. (2007). Remaking U.S. Trade Policy: From Protectionism to Globalization. Ithaca, NY: Cornell University Press. 
Colás, A., \& Mabee, B. (2010). The flow and ebb of private seaborne violence in global politics: Lessons from the Atlantic world, 1689-1815. In: A Colás \& B Mabee (eds). Mercenaries, Pirates, Bandits and Empires: Private Violence in Historical Context (pp. 83-106). New York: Columbia University Press.

Conrad, S. (2016). What is Global History? Princeton: Princeton University Press.

Crossley, N. (2011). Towards Relational Sociology. Abingdon, UK: Routledge.

Drayton, R., \& Motadel, D. (2018). Discussion: the futures of global history. Journal of Global History 13(1), 1-21.

Emirbayer, M. (1997). Manifesto for a relational sociology. American Journal of Sociology 103(2), 281-317.

Figes, O. (1997). A People's Tragedy: The Russian Revolution 1917-1924. London: Pimlico.

Go, J. (2016). Postcolonial Thought and Social Theory. Oxford: Oxford University Press.

Go, J. \& Lawson, G. (eds). (2017). Global Historical Sociology. Cambridge: Cambridge University Press.

Guldi, J. \& Armitage, D. (2014). The History Manifesto. Oxford: Oxford University Press.

Halliday, F. (1994). Rethinking International Relations. Basingstoke: Macmillan.

Halliday, F. (1999). Revolution and World Politics: The Rise and Fall of the Sixth Great Power. London: Macmillan.

Hobden, S., \& Hobson, J. M. (eds). (2002). Historical Sociology of International Relations. Cambridge: Cambridge University Press.

Hobson, J. M., (2006). Mann, the state, and war. In J. A. Hall \& R. Schroeder (eds). An Anatomy of Power: The Social Theory of Michael Mann (pp. 150-166). Cambridge: Cambridge University Press.

Hobson, J., Lawson, G., \& Rosenberg, J. (2010). Historical sociology. In: RA Denemark (ed). The International Studies Encyclopaedia. Oxford: Wiley-Blackwell.

Hoffmann, S., (1959). International Relations: The long road to theory. World Politics 11(3), 346-377. 
Jackson, P. T., \& Nexon D. H. (1999). Relations before states: Substance, process and the study of world politics. European Journal of International Relations 5(3), 291-332.

Keegan, J. (1998). The First World War. London: Random House.

Kennan, G. F. (1957). The Czechoslovak Legion. The Russian Review 16(4), 3-16.

Lachmann, R. (2010). States and Power. Cambridge: Polity.

Lawson, G. (2006). The promise of historical sociology in International Relations. International Studies Review 8(3), 397-423.

Lawson, G. (2015). Revolutions and the international. Theory and Society 44(4), 299-319.

Lawson, G. (2017). A global historical sociology of revolution. In J Go and G Lawson (eds), Global Historical Sociology (pp. 76-98). Cambridge: Cambridge University Press.

Leira, H., \& De Carvalho B. (2010). Privateers of the North Sea: At world's end - French privateers in Norwegian waters. In A. Colás \& B Mabee (eds). Mercenaries, Pirates, Bandits and Empires: Private Violence in Historical Context (pp. 55-82). New York: Columbia University Press.

Mabee, B., \& Vucetic, S. (2018). Varieties of militarism: Towards a typology. Security Dialogue 49(1-2), 96-108.

Mann, M. (2012a). The Sources of Social Power, Volume 1: A History of Power from the Beginning to $A D$ 1760, New Edition. Cambridge: Cambridge University Press.

Mann, M. (2012b). The Sources of Social Power, Volume 2: The Rise of Classes and Nation States, 1760-1914, New Edition. Cambridge: Cambridge University Press.

Mann, M. (2012c). The Sources of Social Power, Volume 3: Global Empires and Revolution, 1890-1945. Cambridge: Cambridge University Press.

Matin, K. (2007). Uneven and combined development in world history: the international relations of state-formation in premodern Iran. European Journal of International Relations 13(3), 419-447.

Matin, K. (2018). Lineages of the Islamic State: An International Historical Sociology of State (De-)Formation in Iraq', Journal of Historical Sociology 31(1), 6-24.

Mawdsley, E. (2017). The Russian Civil War [new edition]. Edinburgh: Birlinn. 
Phillips, A. (2016). Global IR meets global history: Sovereignty, modernity, and the international system's expansion in the Indian Ocean region. International Studies Review 18(1), 62-77.

Poggi, G. (1978). The Development of the Modern State: A Sociological Introduction. Stanford, CA: Stanford University Press.

Rosenau, J. N. (1970). The Adaptation of National Societies: A Theory of Political System Behaviour and Transformation. New York: McCaleb-Seiler.

Rosenberg, J. (2006). Why is there no international historical sociology? European Journal of International Relations 12(3), 307-340.

Rosenberg, J. (2016). International Relations in the prison of Political Science. International Relations 30(2), 127-153.

Rosenberg, J. (2017). The elusive international. International Relations 31(1), 90-103.

Skocpol, T. (2015). States and Social Revolutions: A Comparative Analysis of France, Russia, and China. Cambridge: Cambridge University Press.

Somers, M. R. (1994). Rights, relationality, and membership: Rethinking the making and meaning of citizenship. Law and Social Inquiry 19(1), 63-112.

Spruyt, H. (1994). The Sovereign State and its Competitors. Princeton, NJ: Princeton University Press.

Spruyt, H. (2017). How to integrate global history in International Relations Theory. International Studies Quarterly Online Symposium, 28 November, 8-10. Available at: $<$ https://dataverse.harvard.edu/dataset.xhtml?persistentld=doi:10.7910/DVN/VDZG 7L> (Accessed 13 February 2018).

Strayer, J. R. (2005). On the Medieval Origins of the Modern State, Princeton Classics Edition. Princeton, NJ: Princeton University Press.

Steinmetz, G. (2007). The Devil's Handwriting: Precoloniality and the German Colonial State in Qingdao, Samoa, and Southwest Africa. Chicago: Chicago University Press.

Subrahmanyam, S. (1997). Connected histories: Notes towards a reconfiguration of early modern Eurasia. Modern Asian Studies 31(3), 735-762. 
Subrahmanyam, S. (2007). Holding the world in balance: the connected histories of the Iberian overseas empires, 1500-1640. The American Historical Review 112(5), 13591385.

Thompson, W. (1988). On Global War: Historical-Structural Approaches to World Politics. Columbia, SC: University of South Carolina Press.

Tilly, C. (1992). Coercion, Capital, and European States, AD 990-1992. Oxford: Wiley-Blackwell.

Tilly, C. (1995). Durable inequality. Centre for Studies of Social Change Working Papers Series 224. New York: New School for Social Research.

Trotsky, L. (2017). History of the Russian Revolution [Kindle edition]. London: Penguin.

Waltz, K. (1979). Theory of International Politics. New York: Random House.

Waltz, K. (2001). Man, the State and War: A Theoretical Analysis. New York: Columbia University Press.

Wight, M. (1966). Why is there no international theory?. In H. Butterfield (ed.). Diplomatic Investigations (pp. 17-37). London: George Allen \& Unwin. 